\title{
Teacher's Strategy in Student Deradicalization Efforts through Enforcement of the Pancasila Ideology within Civic Education Materials in Indonesia
}

\author{
Winarno Winarno*, Wijianto Wijianto \\ Department of Pancasila and Civic Education \\ Sebelas Maret University \\ Surakarta, Indonesia \\ *winarnonarmoatmojo@staff.uns.ac.id
}

\begin{abstract}
Pancasila is an ideology and the foundation of national philosophy principle that was final for Indonesia. Although it was final, it does not mean that Pancasila was running and had an impact on the Indonesian people in accordance with national goals. The aimed of the study was to describe the teacher's strategy within to preventing radicalism through enforcement Pancasila ideology in the learning of Vocational High School Citizenship Education as part of the teacher's professional competence. The research method used qualitative descriptive with informant data sources and document studies, and also Focus Group Discussion. The results showed that the teacher's professional competence can be measured based on his ability to develop material related to the Pancasila ideology in Civic Education learning. This can strengthening the ideology of Pancasila and prevent radicalism among students as an effort to deradicalize.
\end{abstract}

Keywords—teachers'strategy; deradicalization; pancasila; civic education

\section{INTRODUCTION}

The issue of global ideology increasingly attracted the attention of the general public related to various phenomena of social development of the new thought and the ideological radicalism issues. The need for a new ideology and identity which is have a capability or able to unite society under one nation's political power, in the history of the Indonesian movement has been done through the founding fathers talks during the first session of the Preparatory Committee for Preparation of Independence (Badan Penyelidik Usaha-usaha Persiapan Kemerdekaan/BPUPK) Efforts from 29 May until June 1, 1945 and a second period of trial between July 10 and July 17, 1945. BPUPK has two main tasks, that are: 1) formulating the foundations of an independent Indonesia and 2) establishing the constitution [1].

The phenomenon of ideology continues always grows up in global society nowadays. For example, one phenomenon that appears and has a bad precedent in society was the phenomenon of religious radicalism and religious fundamentalism which is a bad phenomenon in the world $[2,3]$. Here, there are many criticisms and problems to reinforcement the role of the community, especially the Muslim community, including in Indonesia [4,5,6]. Unfortunately, the phenomenon of fundamentalism itself is destructive, not constructive. Robert N. Bellah, an American sociologist, calls that phenomenon is a scriptural phenomenon. Furthermore, Bellah argues that the tendency of the scripturalist group to see the Qur'an and Sunnah as perfect and holy entities. Those who act like that have made themselves fundamentalists.

Related with data about the issue of radicalism, Mata Air Fondation and Alvara Research Center conducted a survey showing that 23.4 percent of college students and 23.3 percent of high school students agree with jihad for the establishment of an Islamic state or khilafah. Penetration of intolerant teachings has entered among students, then strengthened when becoming a student through studies in the college. Alvara's survey was specifically conducted to measure the attitudes and religious outlook among high school and college students in Indonesia. The survey was conducted on 1,800 students at 25 leading universities in Indonesia, as well as 2,400 excellent high school students in Java and major cities in Indonesia. Students and Students surveyed covered the fields of defense, security, finance, energy, telecommunica-tions, health, education and manufacturing. The research results concluded that High School Students and Students are a search period of identity that is vulnerable to anything, including the teachings of intolerance and radicalism. And students and students will supply labor in the country's strategic sectors. From this survey it is known that there are 23.5 percent of students and 16.3 students state that the Islamic State needs to be fought for for the application of Islam faithfully. It was also explained that the majority of students and students did agree with the Unitary Republic of Indonesia as a form of state compared to the khilafah. However, it should be remembered that there are 17.8 percent of students and 18.3 percent of students who choose Khilafah, not NKRI. Similarly, about the ideology of Pancasila, there are 18.6 percent of students choose Islamic ideology as a state ideology than Pancasila. Whereas among students as many as 16.8 percent chose Islamic ideology rather than Pancasila as an ideology of state [7].

In Indonesia, Pancasila has been accepted by Indonesian people as the basis of the state based on the Preamble of Constitution of 1945 in paragraph IV. Referring to the theory of communitarian citizenship and structural functionalism, Pancasila can be said to be an idea of a good life, is the result 
of community agreement, shared social values that help determine life, a reference to conflict resolution and can be a source for the occurrence of social integration $[8,9]$.

Pancasila is an ideology and the national philosophy priciple that was final for Indonesia. Although it was final, it does not mean that Pancasila is running and has an impact on the Indonesian people in related with national goals. This statement appears, because if looked from various aspects, discussion of ideological problems, values, morals and character development of Indonesia, always encountered various problems that should have been completed by the education process or indocrination of Pancasila for the people of Indonesia. For a third world society like Indonesia, ideological issues become one of three common issues, namely the problems of national integration, the issue of order and political stability, and the ideological problem itself. As stated Darmaputra that the problem of ideology relates to how the process of creating and finding a useful ideology and able to unite the people to achieve common goals [10]. Thus ideology is important for a nation because it gives clarity of national identity, pride, and strength that can inspire to achieve social and political ideals [11].

As the virtue and social values, Pancasila feasible actualized to implemented and socialized to citizens for the existence and survival of the Indonesian nation. This implementation could be done through education channels $[12,13]$. Experience showed that Pancasila was always a part of citizenship education material in Indonesia [14]. The material of Pancasila can be said as the material of Civics that is "The Great Ought" [15], including structural formal content which is fixed and become unifier. In the subject matter of Civic Education based on the current 2013 curriculum, Pancasila material is one of the four main subjects, namely Pancasila, 1945 Constitution, Bhinneka Tunggal Ika and Unitary State of the Republic of Indonesia [16]. The material about Pancasila is the material of ideological indoctrination of the nation in order to counteract the ideals of radicalism which is in conflict with the ideology of the Indonesian nation.

Based on the phenomenon of radicalsime issues, and its relation to the content of Civic Education materials, it is necessary to study the strategy of Civics teachers in the deradicalization process in relation to the content of Civic Education. The Pancasila and Civic Education material in the curriculum 2013 will later be linked to the concept of the status and content of Pancasila and the identification of Pancasila material into citizenship competencies which include Civic Knowledge, Civic Disposition and Civic Skill [16,17]. With this focus, the research problem is formulated, namely how is the content of Pancasila learning material contained in the 2013 curriculum lesson.

\section{THEORETICAL}

\section{A. Deradicalization}

The term of deradicalization is increasingly interesting to study nowadays. The International Crisis Group explains that "Deradicalization can be related to the process of creating an environment that prevents the growth of radical movements by responding to "root causes" that encourage the growth of radical movements" [18]. While Peter Galose explained that "Deradicalization is any effort to neutralize radical ideals through an interdisciplinary approach, such as law, psychology, religion, and socio-culture for those who are influenced or exposed to radical understanding and or pro-violence" [19].

Furthermore, Agus explained that "Deradicalization is intended to transform someone who was originally radical into not radical, including among others by alienating them from the radical group they belong to" [19]. The statement gives an understanding that deradicalization is a process of creating an environment that prevents the growth of radicalism through various approaches to change someone who was originally radical to be not radical.

According to Yusuf Qardlawi who explained that "Radicalism means etymologically is to stand extreme and far from the middle position, or beyond the limits of reason. whereas in terms of terminology, radicalism is fanatical to one opinion and negates the opinions of others, ignores the historicity of religion, does not dialogue, and literally in understanding religious texts without considering the essential objectives of Shari'a" [20].

Indonesian Council of Ulama stated that "Radicalism is an understanding and action that is attached to a person or group that wants change, both in the social, political fields by using violence, thinking basicly and acting extreme". According to Thohir "Radicalism is an understanding that contrasts sharply between the values championed by a group with values that are in force or already established. Furthermore, Qodir stated that radicalism is an understanding that requires a change, change and breakdown of a system in the community until it's predicament. Whenever necessary use violent means. Radicalism wants a total change in a condition or all aspects of community life [21].

Such actions according to Raimundo Panningkar referred to as "lazy tolerance. Lazy tolerance is a form of tolerance that only appears to be lipped, but its mind does not agree (justify and agree) the spirit of external tolerance " [21]. In line with the statement, Bassam Tibi argued that "They are anti-people with foreign terms such as democracy, pluralism, tolerance, liberalization, capitalism and secularization" [19].

Based on the description above, it can be concluded that deradicalization is a process of creating a peaceful environment by preventing the growth of radicalism by changing someone who was originally radical into not radical. Radicalism is grouped into two forms, in the form of radicalism thinking is an idea while in the form of radicalism action in the form of acts of violence and the potential to become terrorists. This is due to internal factors (understanding extreme religious teachings) and external factors (global political dynamics).

\section{B. The Ideology of Pancasila}

Pancasila is the principle philosophy and the basis nation for Republic of Indonesia whose contents are contained in the Preamble of the 1945 Constitution in paragraph IV. Pancasila derived from Sanskrit, which means five basist or five moral principles, was taken over by Sukarno but by giving him new 
content and meaning [22]. The term Pancasila which originally served as moral and ethical guidance has been transformed into a political concept in the context of modern Indonesian political thought [11]. The objective existence of Pancasila is in its relationship with the unitary state of the Republic of Indonesia, namely as the basis of the state, source of law and national ideology [23].

Pancasila can be distinguished in formulas or status and content or content [16,27]. The formula of Pancasila is the position of Pancasila while the content of Pancasila is the meaning that is held in every sila. The position of Pancasila as a pluralistic status [23]. There are indeed various definitions, positions, and functions of Pancasila, each of which must be understood in accordance with its context [24]. The position of Pancasila can be in the form of Pancasila as the basis of the state, national ideology, view of the nation, source of law, national identity, unifying the nation, national soul and personality, cultural identity, national political conception, and national ideals [25]. The content of Pancasila is the content contained in Pancasila which can be interpreted through various thinking approaches namely philosophical, theological, juridical, sociological and historical approaches [23].

\section{The Material of Civic Education}

Learning materials or instructional materials outline consist of knowledge, attitudes, and skills that students must learn in order to achieve predetermined competencies. In detail learning material consists of material that is knowledgeable (facts, concepts, prepositions, principles, theories), material skills (procedures, procedures), and material that is of a value.

Regarding citizenship education, Isin and Turner explained that there is no doubt that citizenship has also emerged as a major theme connecting policy domains that range from welfare, education, and labor markets to international relations and migration. Citizenship connects these because it brings within its orbit three fundamental issues: how the boundaries of membership within a polity and between polities should be defined (extent); how the benefits and burdens of membership should be allocated (content); and how the 'thick-ness' of identities of member should be comprehended and accommodated (depth") [26].

The above statement shows that the study of citizenship is greatly influenced by the study of disintegration issues including the issue of radicalism. Then in essence that every country has a way or strategy in the process of planting ideology, in Indonesia the ideology is the ideology of Pancasila.

\section{Civics Competence}

The main components of good Citizenship Education include 3 (three) things, namely civic knowledge, civic skills, and civic dispotitions Civic knowledge relating to the content or what citizens should know. Civic skills are what skills should be owned by citizens that include; intellectual skills and participation skills. While civic dispotitions relate to the private and public character of citizens that need to be maintained and enhanced in constitutional democracy [17].
Citizenship competence was very important to be owned by citizens as a shield in dealing with all kinds of issues that appears in the community.

\section{METHOD}

This research used qualitative descriptive method in the form of document study with content analysis technique. The unit analyzed is the material content of Civics and Pancasila covering 2 (two) sub units namely the concept of status and content of Pancasila; and Pancasila linkage with Civic Knowledge, Civic Disposition and Civic Skill components in Civics. The object of analysis is a sentence containing the word Pancasila.

The qualitative research is research that dwell on the data attached to the informant, to then digug and terukuk with data in the form of documents, pictures or video. Data collection techniques in this study was done by focus group discussion which participants are teachers Civic Education Vocational High School in around Surakarta residency include Klaten, Karanganyar, Boyolali, Wonogiri, Sukoharjo, Sragen and the Surakarta.

The document analyzed in this study was the analysis of the contents of "Pancasila" as the nation's ideology will be analyzed based on the categories: the position of Pancasila and the contents of Pancasila or the category of formulas and the contents of Pancasila or the status and content of Pancasila $[16,27]$. Subsequent subsequent analysis is the mapping of citizenship competence which includes Civic Knowledge, Civic Disposition and Civic Skill related to Pancasila. The documents analyzed were Attachment 20 of Minister of Education and Culture Regulation No. 24 of 2016 concerning Basic Competencies of Pancasila Education and Citizenship of Senior High School/Madrasah Aliyah/ Vocational High School/Vocational Aliyah Madrasah.

Data analysis using interactive analysis, while the data presentation categorized into 2 things. First, the teacher's strategy in efforts to deradicalize students and analyze the content of Pancasila ideological material regarding status and content and two, the material content of Pancasila is associated with the Civic Knowledge component, Civic Disposition and Civic Skills.

\section{RESUlt AND DisCUSSION}

\section{A. Teacher's Strategy in Student Deradicalization Efforts}

The teacher has the task of educating students with varying capacities or competencies. One of the tasks of the teacher is to "take care" of students through the education system which is carried out from a variety of negative things that continue to emerge along with the development of technology, information and communication.

Based on data obtained from informants, Civic Education teachers explained that the phenomena that occur today are related to information phenomena. That is, the teachers explained that what is happening now is that students receive information from various sources that are not clear. These sources generally come from social media communication 
networks, and contradictory contradictions with the material described by the teacher. For this reason the teacher must have a strategy in the learning process in order to correct all information that is not yet certain of its truth, especially related to the issue of radicalism that students receive as strengthening ideology for students.

This statement was supported by the results of research conducted by Mahfud which explained that information development is currently very risky and massive. The targets of the various information that lead to the change of mindset and ideology were more directed to the youth. This is what can then bring a new generation that has a mindset that is not desired by the nation's ideology, namely the mindset of radicalism and is usually associated with the religious context [28].

The teacher strategy that is carried out in the student deradicalization process is by optimizing the teacher's professional competence by performing the role of the teacher of Pancasila and Civic Education, including: The role as a learning designer, namely the role of the Pancasila and Civic Education teacher in formulating a learning plan. At least the design instructional draft was used for the following points: Formulating learning objectives, by placing tolerance as goals and character building that must be achieved within the scope of Unity in Diversity in class X and XI on Key Performance 3.7 and Pancasila in class XII on Key Performence 1.3 prepare learning materials that make students think critically by integrating social phenomena that occur in the community in the learning process. Determine models and methods that are student-centered, such as inquiry learning models, discovery learning, and problem based learning, and contextual teaching and learning. While the method of discussion, quiz, and group work. Providing learning resources, such as the 2013 curriculum book, student worksheet and the Internet to support the development of science. Planning effective and efficient learning media, namely power, video, pictures and caricatures. In addition, in terms of the role as a learning manager, namely the role of Civic Education teachers in managing learning by giving assignments and dividing students into several discussion groups. In addition, Civic Education teachers also utilize several learning media, such as power point, video and internet as a source of student learning. However, the role of Civic Education teachers as learning management has not been optimal, this is indicated by the presence of students who were not paying attention at the discussion.

\section{B. Learning Material of Civic Education in 2013 Curriculum}

In the 2013 curriculum, the material that is filled with knowledge is reflected in the formula of Core Competence 3 (CC 3) which is further elaborated in the Key Performence (KP) formula. Thus it could be said the formulation of Key Performence in Competence Core 3 contains knowledge material. Pancasila is one of the four main subjects in 2013 Curriculum of Civic Education namely Pancasila, 1945 Constitution, Bhineka Tunggal Ika and The Unitary State of the Republic of Indonesia. These four core subjects of Civic Education were referred to as the four basic consensus of nationality, formerly known as the four pillars of national and state life [29]. Regarding Pancasila learning, the following findings are presented:
TABLE I THE FORMULATION OF PANCASILA COMPETENCE IN KEY PERFORMENCE (KP) 3 AT VOCATIONAL HIGH SCHOOL

\begin{tabular}{|l|l|}
\hline \multicolumn{1}{|c|}{ Competence Formula } & \multicolumn{1}{|c|}{ Place } \\
\hline $\begin{array}{l}\text { Analyze the values of Pancasila within the } \\
\text { framework of the governance practice }\end{array}$ & $\begin{array}{l}\text { KP 3.1 Vocational } \\
\text { High School X }\end{array}$ \\
\hline $\begin{array}{l}\text { Analyzing human rights violations in the } \\
\text { perspective of Pancasila in the life of nation and } \\
\text { state }\end{array}$ & $\begin{array}{l}\text { KP 3.1 Vocational } \\
\text { High School XI }\end{array}$ \\
\hline $\begin{array}{l}\text { Analyzing the values of Pancasila related to cases } \\
\text { of rights violation and denial of obligations by the } \\
\text { citizens in the life of nation and state }\end{array}$ & $\begin{array}{l}\text { KP 3.1 Vocational } \\
\text { High School XII }\end{array}$ \\
\hline
\end{tabular}

Based on the findings above, it was known that Pancasila content in Civic Education 2013 Curriculum at Vocational High School level contains: First, Pancasila material is always contained in the first sequence of Basic Competence formulation and there is one formula containing Pancasila from each group of Key Performance available. Two, the content emphasizes the status of Pancasila as the basis of the state and the view of the nation's life. Three, Pancasila learning materials include; history of Pancasila formulation and stipulation, Pancasila values related to the framework of practice of state administration, Pancasila based community dynamics, Pancasila perspective on human rights and Pancasila values related to cases of rights violation and denial of citizens' obligations. Four, the contents of the status of Pancasila as the basis of the state and the view of life of the nation are not further described.

Furthermore, the Pancasila formula is presented in relation to the Civic Knowledge component, Civic Disposition and Civic Skill. It can be stated that the formulation of Civic Knowledge regarding Pancasila has been reflected in the formulation of Core Competence 3 (CC 3) item 3.1. Based on the findings, the contents of the Civic Knowledge regarding Pancasila in the 2013 Curriculum at the vocational high school level are as follows:

- The process of formulating and stipulating Pancasila as the basis of the state

- Pancasila as the basis of the state and the nation's way of life

- Events and dynamics that occur in society with the ideal practice of Pancasila

- Pancasila values in the framework of the practice of state governance

- Violations of human rights in the perspective of Pancasila

- Pancasila values related to cases of rights violations and denial of citizens' obligations

TABLE II. THE FORMULATION OF PANCASILA COMPETENCE IN KEY PERFORMENCE (KP) 1 AT VOCATIONAL HIGH SCHOOL

\begin{tabular}{|l|l|}
\hline \multicolumn{3}{|c|}{ Competence Formula } & Place \\
\hline Grateful for the values of & KP 1.1 Vocational High School X \\
Pancasila in the practice of & \\
administering the State as one of & \\
form devotion and believe in & \\
God
\end{tabular}




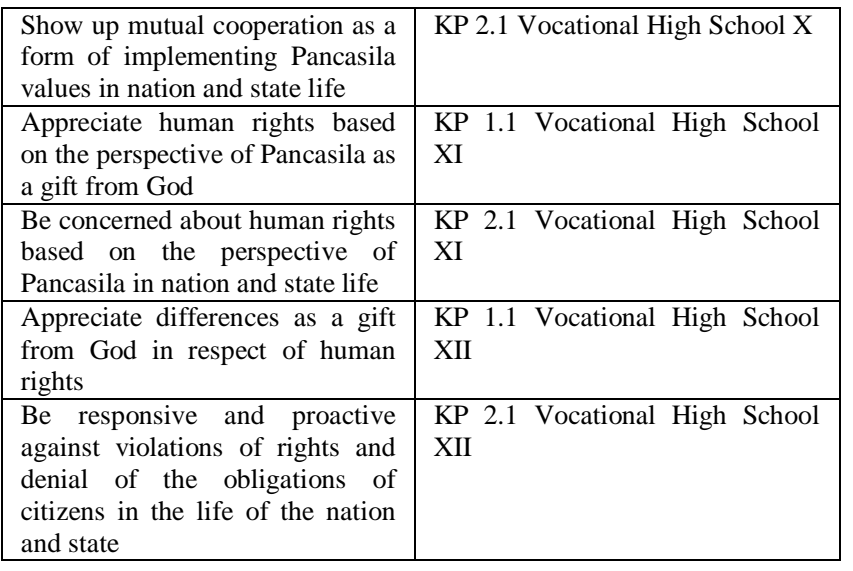

Based on the table above, it can be stated that the content of Civic Disposition related to Pancasila content includes character, as follows:

- thank to The God

- responsibility

- committed as an Indonesian citizen

- proud of the homeland

- team work

- respect to human rights

- caring for human rights

- appreciate the difference

- responsive and proactive towards violations of rights and denial of citizens' obligations

The content of Civic Skill related to Pancasila content is contained in the formula of Core Competence 4 (CC 4) which is further the formulation was elaborated in the Key Performance Group 4. The formulation is as follows:

TABLE III. THE FORMULATION OF PANCASILA COMPETENCE IN KEY PERFORMENCE (KP) 4 AT VOCATIONAL HiGH SCHOOL

\begin{tabular}{|l|l|}
\hline \multicolumn{1}{|c|}{ Competence Formula } & \multicolumn{1}{|c|}{ Place } \\
\hline $\begin{array}{l}\text { Presenting the results of the analysis of Pancasila } \\
\text { values in the framework of the governance practice }\end{array}$ & $\begin{array}{l}\text { KP 4.1 Vocational } \\
\text { High School X }\end{array}$ \\
\hline $\begin{array}{l}\text { Presenting the results of the analysis of human } \\
\text { rights violations in the perspective of Pancasila in } \\
\text { the nation and state life }\end{array}$ & $\begin{array}{l}\text { KP 4.1 Vocational } \\
\text { High School XI }\end{array}$ \\
\hline $\begin{array}{l}\text { Presenting the results of the analysis of Pancasila } \\
\text { values related to cases of rights violations and } \\
\text { denial of citizens' obligations in the nation and } \\
\text { state life }\end{array}$ & $\begin{array}{l}\text { KD 4.1 Vocational } \\
\text { High School XII }\end{array}$ \\
\hline
\end{tabular}

Based on the table above, the component of citizenship skills regarding Pancasila is manifested in the form of intellectual ability that is the ability to present the results of analysis, the ability to design research and the ability to conduct research. The intellectual skills are related to the Pancasila material as contained in the Key Performence group 3. The Key Performance 4 groups as a reflection of the competence of skills have a bearing on the formulation in the Key Performence Group 3.

Based on the findings of the study, the contents of the Pancasila material contained in the 2013 Curriculum of Civic Education subjects are grouped into 2 (two) categories. First, material that contains the status, position, role, or function of Pancasila in the life of the Indonesian nation and state. Two, material containing the contents contained in the concept of Pancasila itself. Based on this categorization, it can be concluded that the material of Pancasila in Civics contains 2 (two) things which are matter of formula or existence and matter of content or substance of Pancasila.

The categories of status and content of Pancasila in Civic Education 2013 Curriculum, as follows:

TABLE IV. THE FORMULATION OF STATUS AND CONTENT OF PANCASILA

\begin{tabular}{|l|l|l|}
\hline $\begin{array}{l}\text { Learning } \\
\text { Material }\end{array}$ & \multicolumn{1}{|c|}{$\begin{array}{c}\text { Material : as a } \\
\text { Status }\end{array}$} & \multicolumn{1}{c|}{ Material : as a Content } \\
\hline Pancasila & $\begin{array}{l}\text { Pancasila as a } \\
\text { national principle } \\
\text { Pancasila as the } \\
\text { way of life }\end{array}$ & $\begin{array}{l}\text { a. Pancasila values related to events } \\
\text { and the dynamics within community } \\
\text { b. Pancasila value related to } \\
\text { governance administration practices } \\
\text { c. Pancasila value related to rights } \\
\text { violations and denial of citizens' } \\
\text { obligations } \\
\text { d. Perspective of Pancasila related to } \\
\text { human rights violations }\end{array}$ \\
\hline
\end{tabular}

Based on the findings of the study, it is known that the material status of Pancasila contained in the 2013 Civic Education Curriculum was Pancasila as the national principle and Pancasila as the nation's way of life. Then what is the content of Pancasila as the national principle and the way of life for the nation, needs to be analyzed through academic and juridical thinking that develops in Indonesia.

Pancasila as the national principle was used as a basis for regulating governance administration. The basic Pancasila of the state is a juridical understanding of constitutionality [25]. The constitutional process of Pancasila pouring into paragraph IV of the Preamble of the 1945 Constitution of the Republic of Indonesia makes Pancasila the source of state law of the Republic of Indonesia [23]. The basic Pancasila of the state has both juridical and political implications. By making Pancasila the basis of the state, all aspects of state administration are based and imbued with the values of Pancasila [12]. Pancasila as a national principle has juridical implementation which is to become a legal ideal (rechtsidee) which must be the basis and purpose of every law in Indonesia [28]. The basis of the state in question is directed as a guidance to carry out moral obligations for the leadership and the state government [30]. So the meaning of the basic Pancasila of the state is more related to organizing the state, namely from the juridical side of the state administration and its values to be the moral obligation of the state administrators to carry it out.

Pancasila as the national principle has juridical and political implications in the practice of statehood, it has also caused ethical implications for state and citizen organizers. The juridical implication of the basic Pancasila of the state is to 
make Pancasila a legal source. With the Pancasila process becomes the basis of the state then also makes Pancasila the source of law of the Republic of Indonesia [23]. The political implication of the basic Pancasila of the state is to make Pancasila values as a common goal and a means of unifying the Indonesian nation. The ethical implications of the bas

Pancasila of the state are the basis of the intended state is directed as guidance to carry out moral obligations for the leadership and government of the state [30]. These traits provide moral guidance to the leader or government of the state, the guidance for the state organizers not to deviate from the straight path to achieve the happiness of the people, world peace and brotherhood among nations.

The nation's way of life is the crystallization and institutionalization of the values it possesses, is believed to be true and creates a determination to make it happen. Pancasila view of life of the nation are the five noble values of the nation that has experienced crystallization and institutionalization, received, believed to be good and right, and give encouragement to make it happen. Pancasila as the way of life of the Indonesian nation is the crystallization of social values of the Indonesian nation that is believed to be true and inspires to make it happen [31].

Based on the findings of this research, the researcher stated that the material of Pancasila status as national principle and the nation's way of life needs to be continued with the content of Pancasila namely the content of the basic Pancasila state and Pancasila as the nation's coherent view of life. Coherence is important because as a concept of academic as well as the political conception of Indonesia that contains virtue, Pancasila needs to be consistent between status and content. Meanwhile, the material on the perspective of Pancasila is a continuation of the material status and content of Pancasila. The material "Perspective of Pancasila related to human rights violations" contained in Basic Competency 3 can be seen as a further development of Pancasila content material which is Pancasila perspective material.

The description of the material of Pancasila in Civic Education 2006 Curriculum was related to the material of Pancasila in the 2013 Civic Education Curriculum, and this is the scheme:

TABLE V. THE CONTENT OF PANCASILA WITHIN 2006 AND 2013 CIVIC EDUCATION CURRICULUM

\begin{tabular}{|c|c|c|c|}
\hline $\begin{array}{c}\text { Pancasila } \\
\text { Material } \\
\text { within 2006 } \\
\text { Curriculum }\end{array}$ & $\begin{array}{l}\text { Material of } \\
\text { "status" } \\
\text { Pancasila }\end{array}$ & $\begin{array}{lr}\text { Material of } \\
\text { "content" Pancasila }\end{array}$ & $\begin{array}{l}\text { Material } \\
\text { "perspektif" } \\
\text { Pancasila }\end{array}$ \\
\hline $\begin{array}{c}\text { Pancasila } \\
\text { Material } \\
\text { within } 2013 \\
\text { Curriculum }\end{array}$ & $\begin{array}{l}\text { Pancasila as } \\
\text { a national } \\
\text { principle } \\
\text { Pancasila as } \\
\text { a way of life }\end{array}$ & $\begin{array}{l}\text { The values of } \\
\text { Pancasila were } \\
\text { related to the } \\
\text { dynamics of } \\
\text { society, the } \\
\text { practice of the } \\
\text { governance, and } \\
\text { the violation of } \\
\text { human rights }\end{array}$ & $\begin{array}{l}\text { Perspective of } \\
\text { Pancasila against } \\
\text { rights violation and } \\
\text { denial of citizen } \\
\text { obligation }\end{array}$ \\
\hline
\end{tabular}


The competence of citizenship skills that is intellectual ability includes the ability to present an analysis of cases related to the status and value of Pancasila values. While the competence of participatory skills has not been seen. Citizenship attitude competencies include personal (private) attitudes and (public) social attitudes.

\section{CONCLUSION}

Nowadays, the phenomenon of information dissemination about various types of news is very massive, including the dissemination of information about the principle ideas that are contrary to Pancasila which is packaged in an interesting information and often associated with things that are beliefs such as religion. This dissemination of information tends to lead to young people or students, therefore, teachers have an important role to participate in educating their students so as not to be influenced by the principle ideas that are contrary to Pancasila through deradicalization strategies in the learning process. Pancasila is one of the 4 (four) material of the 2013 Curriculum Civic Education, namely Pancasila, 1945 Constitution of the Republic of Indonesia, Bhineka Tunggal Ika and the unity Republic of Indonesia. The material of Pancasila in 2013 Curriculum Civic Education is presented in 2 (two) materials, which are material about "status" of Pancasila and material about "content" of Pancasila. The Pancasila status material contains Pancasila material as the national principle and Pancasila as the nation's way of life. The contents of Pancasila include: The Pancasila material in the 2013 Curriculum Civic Education can be broken down into 3 civic competencies, namely civic knowledge, civic skills and civic attitudes.

It is recommended that the material of Pancasila status to be the national principle and the nation's way of life in Pancasila content consistently. That is the meaning of each value and actualization of that value in the life of the nation and state. The material perspective of Pancasila should be abolished. Pancasila "perspective" material is more appropriately taught in higher education.

\section{REFERENCES}

[1] Silalahi, Dasar-Dasar Indonesia Merdeka Versi Para Pendiri Negara, Jakarta: Gramedia, 2001.

[2] K. Amstrong, Holy War: The Crusades and Their Impact on Today's World, New York: Anchor Books, 1991.

[3] A. Azra, Konflik Baru Antar Peradaban Globalisasi, Radikalisme \& Pluralisme, Jakarta: Raja Grafindo Persada, 2002.

[4] M. Abdurrahman, Islam sebagai Kritik Sosial, Jakarta: Erlangga, 2003.
[5] M. Ali, Islam and Colonialism: Becoming Modern in Indonesia and Malaya. Edinburgh: Edinburgh University Press, 2016.

[6] A.B. Baasyir, Teroris Melawan Teroris, Yogyakarta: Mawazin, 2007.

[7] A. Hasanudin, Survei Paham Radikal, 2017.

[8] W. Kymlicka, Politics in the Vernacular: Nationalism, Multiculturalism, and Citizenship, Oxford: Oxford University Press, 2001.

[9] G. Ritzer, Sosiologi Ilmu Pengetahuan Berparadigma Ganda, Jakarta : Rajawali Press, 2004.

[10] E. Darmaputra, Pancasila antara Identitas dan Modernitas Tinjauan Etis dan Budaya, Jakarta: Gunung Agung, 1997.

[11] F. Ismail, Ideologi Hegemoni dan Otoritas Agama, Wacana Ketegangan Kreatif Islam dan Pancasila, Yogyakarta: Tiara Wacana, 1999.

[12] Kaelan, Revitalisasi dan Reaktualisasi Pancasila sebagai Dasar Filsafat Negara dan Ideologi dalam Memaknai Kembali Pancasila, Yogyakarta: Penerbit Lima, 2007.

[13] M. Sastrapetedja, Pancasila sebagai Prinsip Humanisasi Masyarakat Kontekstualisasi dan Implementasi Pancasila dalam Memaknai Kembali Pancasila, Yogyakarta: Penerbit Lima, 2007.

[14] F.K. Kalidjernih, Puspa Ragam, Konsep dan Isu Kewarganegaraan, Bandung: Widya Aksara Press, 2007.

[15] M.N. Somantri, Menggagas Pembaharuan Pendidikan IPS, Bandung: Rosda Karya, 2001.

[16] Winarno, Implementasi Pancasila melalui Pendidikan Kewarganegaraan dalam mengembangkan Jatidiri Bangsa, Disertasi Sekolah Pascasarjana UPI Bandung. 2011

[17] S.M. Branson, The Role of Civic Education, A Forthcoming Education Policy Task Force Position Paper from the Communitarian Network. Available at www.civiced.org, 1998.

[18] Rokhmad, "Pandangan Kiai Tentang Deradikalisasi Paham Islam Radikal Di Kota Semarang", Jurnal Analisa, vol. 21, pp. 25-36, November 2014

[19] S.B. Agus, Darurat Terorisme: Kebijakan Pencegahan, Perlindungan dan Deradikalisasi, Jakarta: Daulat Press, 2014.

[20] I. Masduqi, Berislam Secara Toleran: Teologi Kerukunan Antar Umat Beragma, Bandung: Mizan, 2011.

[21] Z. Qodir, Radikalisme Agama Indonesia, Yogyakarta: Pustaka Pelajar, 2014.

[22] S. Maarif, Islam dan Masalah Kenegaraan. Studi tentang Percaturan dalam Konstituante, Jakarta: LP3S, 1985.

[23] A.M.W. Pranarka, Sejarah Pemikiran Pancasila, Jakarta: CSIS, 1985.

[24] Kaelan, Negara Kebangsaan Pancasila, Yogyakarta: Paradigma, 2013.

[25] D. Darmodihardjo, Santiaji Pancasila, Surabaya: Pustaka Nasional, 1981.

[26] E.F. Isin and B.S. Turner, Handbook of Citizenship Studies, London, SAGE Publications Ltd: British Library Cataloguing in Publication data, 2002.

[27] Notonagoro, Pancasila secara Ilmiah Populer Cet ke-5, Jakarta: CV Pantjuran Tudjuh, 1980

[28] M. Mahfud, Konstitusi dan Hukum dalam Kontroversi Isu, Jakarta: Rajawali Perss, 2008.

[29] MPR RI, Empat Pilar Kehidupan Berbangsa dan Bernegara, Jakarta: Sekretariat MPR RI, 2012.

[30] M. Hatta, Demokrasi Kita, Jakarta: Pandji Masyarakat, 1966.

[31] A.M. Toyibin, and K.A. Djahiri, Pendidikan Pancasila, Jakarta: PT Rineka Cipta, 1997. 